\title{
Parathyroid Hormone Gene Expression in Hypophosphatemic Rats
}

Rachel Kilav, Justin Silver, and Tally Naveh-Many

Minerva Center for Calcium and Bone Metabolism, Nephrology Services, Hadassah University Hospital, Jerusalem il-91120, Israel

\begin{abstract}
Phosphate is central to bone metabolism and we have therefore studied whether parathyroid hormone (PTH) is regulated by dietary phosphate in vivo. Weanling rats were fed diets with different phosphate contents for 3 wk: low phosphate $(0.02 \%)$, normal calcium $(0.6 \%)$, normal phosphate $(0.3 \%)$, and calcium $(0.6 \%)$; high phosphate $(1.2 \%)$, high calcium (1.2\%). The low phosphate diet led to hypophosphatemia, hypercalcemia, and increased serum $1,25(\mathrm{OH})_{2} \mathrm{D}_{3}$ together with decreased PTH mRNA levels $(25 \pm 8 \%$ of controls, $P<0.01)$ and serum immunoreactive PTH (4.7 $\pm 0.8: 22.1 \pm 3.7 \mathrm{pg} / \mathrm{ml}$; low phosphate: control, $P$ $<0.05)$. A high phosphate diet led to increased PTH mRNA levels. In situ hybridization showed that hypophosphatemia decreased PTH mRNA in all the parathyroid cells. To separate the effect of low phosphate from changes in calcium and vitamin D rats were fed diets to maintain them as vitamin D-deficient and normocalcemic despite the hypophosphatemia. Hypophosphatemic, normocalemic rats with normal serum 1,25( $\mathrm{OH})_{2} \mathrm{D}_{3}$ levels still had decreased PTH mRNAs. Nuclear transcript run-ons showed that the effect of low phosphate was posttranscriptional. Calcium and $1,25(\mathrm{OH})_{2} \mathrm{D}_{3}$ regulate the parathyroid and we now show that dietary phosphate also regulates the parathyroid by a mechanism which remains to be defined. (J. Clin. Invest. 1995. 96:327-333.) Key words: parathyroid cells • calcium - 1,25-dihydroxyvitamin $D_{3} \cdot$ secondary hyperparathyroidism - phosphate $\cdot$ parathyroid hormone
\end{abstract}

\section{Introduction}

Parathyroid hormone (PTH) ${ }^{1}$ gene expression is known to be regulated by 1,25 -dihydroxyvitamin $\mathrm{D}_{3}\left(1,25(\mathrm{OH})_{2} \mathrm{D}_{3}\right)$, cal-

The results of this study were presented in part at the American Society of Bone and Mineral Research, Tampa, FL, 18-22 September 1993, Kansas City, MO, 9-13 September 1994, and were published in abstract form (1993. J. Bone Miner. Res. 8:S200; 1994. J. Bone Miner. Res. 9:S338).

Address correspondence to Justin Silver, Mineral Metabolism Unit, Hebrew University School of Medicine, Hadassah University Hospital, P.O. Box 12000, 91120, Jerusalem, Israel. Phone: 011-972-2436-778; FAX: 011-972-2421-234.

Received for publication 7 November 1994 and accepted in revised form 27 February 1995.

1. Abbreviations used in this paper: $1,25(\mathrm{OH})_{2} \mathrm{D}_{3}, 1,25$-dihydroxyvitamin $D_{3} ;$ iPTH, immunoreactive parathyroid hormone; PTH, parathyroid hormone; VDR, vitamin $\mathrm{D}$ receptor.

J. Clin. Invest.

(c) The American Society for Clinical Investigation, Inc. 0021-9738/95/07/0327/07 \$2.00

Volume 96 , July $1995,327-333$ cium, and estrogens (1). 1,25(OH $)_{2} \mathrm{D}_{3}$ decreases PTH gene transcription both in vivo in rats (2) and in vitro in primary cultures of bovine parathyroid cells (3), as well as in a stably transfected cell line $(4,5)$. In vivo in rats hypocalcemia increases PTH mRNA levels (6-8). Estrogens also lead to an increase in PTH mRNA levels (9).

Hyperphosphatemia leads to a decrease in serum calcium and $1,25(\mathrm{OH})_{2} \mathrm{D}_{3}$ levels, and hypophosphatemia to an increase in serum $1,25(\mathrm{OH})_{2} \mathrm{D}_{3}$ levels $(10)$. Because of the importance of the phosphate retention of chronic renal failure to the pathogenesis of secondary hyperparathyroidism, as well as the importance of phosphate to normal physiology, we have now studied the effects of phosphate on PTH gene expression in vivo in rats. Our present study shows that changes in dietary phosphate regulate PTH gene expression and serum PTH levels.

\section{Methods}

Animals. Weanling male Hebrew University strain rats were maintained for $3 \mathrm{wk}$ on the following diets (Teklad Premier Laboratory Diets, Madison, WI): Low phosphate, normal calcium $(0.02 \%$ phosphate, $0.6 \%$ calcium); normal phosphate, normal calcium $(0.3 \%$ phosphate, $0.6 \%$ calcium); high phosphate, high calcium ( $1.2 \%$ phosphate, $1.2 \%$ calcium); vitamin D-deficient, low phosphate, low calcium $(0.02 \%$ phosphate, $0.02 \%$ calcium). After 1-21 d the thyroparathyroid tissue was excised under pentobarbital anesthesia, and blood samples taken. All rat surgery was performed at 9:00-10:00 a.m. The excised tissue was immediately frozen in liquid nitrogen and stored at $-70^{\circ} \mathrm{C}$ until extraction.

Second generation vitamin $D$-deficient rats. Female rats were maintained on vitamin D-free diets from weaning until maturity and their offspring fed diets with no vitamin D and low or normal phosphate concentrations (as above). In another experiment second generation vitamin D-deficient rats were fed a vitamin D-deficient diet low in both phosphate and calcium (as above).

Measurement of cellular mRNA levels. RNA was extracted from rat thyroparathyroid tissue and the levels of PTH mRNA were measured by Northern blots after extraction with TRI Reagent (Molecular Research Center, Inc., Cincinnati OH). RNA was denatured and ethidium bromide was added to each sample at a concentration of $0.1 \mathrm{mg} / \mathrm{ml}$. The samples were size-fractionated by electrophoresis on $1.25 \%$ agarose gels containing formaldehyde and transferred to Hybond filters (Amersham International, Little Chalfont, United Kingdom) by diffusion blotting. The integrity of the RNA and the uniformity of RNA transfer to the membrane were determined by ultraviolet visualization of the ribosomal RNA bands of the gels and the filters. The filters were fixed by ultraviolet cross-linking and hybridized as previously described $(2,9)$. Hybridization was to a random primed rat PTH cDNA (a gift of $\mathrm{H}$. Meyer, Gesellschaft für Biotechnologische Forschung, Braunschweig, Germany) and 18S RNA (gift of M. A. Levine, Johns Hopkins Hospital, Baltimore, MD).

Nuclear run-on transcription assay. Thyroparathyroid tissue from 10 rats was homogenized with a polytron in $0.25 \mathrm{M}$ sucrose, $10 \mathrm{mM}$ Hepes pH $0.8,10 \mathrm{mM} \mathrm{MgCl}_{2}, 2 \mathrm{mM}$ DTT, and $0.1 \%$ Triton X-100 (homogenization buffer). Nuclei were pelleted at $500 \mathrm{~g}$ at $4^{\circ} \mathrm{C}$ for 5 $\mathrm{min}$, then resuspended in homogenization buffer. The nuclear suspension was layered over a sucrose cushion consisting of $1 \mathrm{M}$ sucrose, $10 \mathrm{mM}$ Hepes (pH 8.0), $10 \mathrm{mM} \mathrm{MgCl}_{2}, 2 \mathrm{mM}$ DTT, and $0.1 \%$ Triton X-100, 
Table I. The Effects of 3 wk of Diets Given to Weanling Rats

\begin{tabular}{cccc}
\hline & $\begin{array}{c}\text { Serum phosphate } \\
(\text { mean } \pm \text { SE }[n])\end{array}$ & $\begin{array}{c}\text { Serum calcium } \\
(\text { mean } \pm \mathrm{SE}[n])\end{array}$ & $\begin{array}{c}\text { Serum 1,25(OH) } \mathrm{D}_{3} \\
(\text { mean } \pm \mathrm{SE}[n])\end{array}$ \\
\hline$m g / d l$ & $m g / d l$ & $p g / m l$ \\
& $m$ & & \\
$\begin{array}{c}\text { Low phosphate, } \\
\text { normal calcium }\end{array}$ & $4.0 \pm 0.4(4)^{\ddagger}$ & $12.6 \pm 0.6(4)^{*}$ & $>400(4)^{\ddagger}$ \\
$\begin{array}{c}\text { Normal phosphate, } \\
\text { normal calcium }\end{array}$ & $9.8 \pm 1.2(4)$ & $10.6 \pm 0.4(4)$ & $68 \pm 28.3(4)$ \\
$\begin{array}{c}\text { High phosphate, } \\
\text { high calcium }\end{array}$ & $9.4 \pm 0.8(4)$ & $11.1 \pm 0.6(4)$ & $30 \pm 5.9(4)^{*}$ \\
\hline
\end{tabular}

$n$, number of rats. ${ }^{*} P<0.05$, or ${ }^{\ddagger} P<0.01$ compared with normal phosphate, normal calcium.

and pelleted at $500 \mathrm{~g}$ at $4^{\circ} \mathrm{C}$ for $5 \mathrm{~min}$. Nuclei were resuspended in $40 \%$ glycerol, $5 \mathrm{mM} \mathrm{MgCl} 2,50 \mathrm{mM}$ Tris, and $0.1 \mathrm{mM}$ EDTA (storage buffer), then frozen in liquid nitrogen, and stored at $-70^{\circ} \mathrm{C}(11)$. For the run-on assay (12) nuclei were thawed on ice, then incubated in 200$\mu$ l reaction mixture containing $30 \%$ glycerol, $2.5 \mathrm{mM}$ DTT, $1 \mathrm{mM}$ $\mathrm{MgCl}_{2}, 70 \mathrm{mM} \mathrm{KCl}, 0.5 \mathrm{mM}$ each of ATP, CTP, and GTP, $1 \mathrm{mg} / \mathrm{ml}$ heparin, $100 \mu \mathrm{Ci}$ of $\left[{ }^{32} \mathrm{P}\right] \mathrm{UTP}(800 \mathrm{ci} / \mathrm{mmol})$, and $100 \mathrm{U}$ RNase inhibitor, for $20 \mathrm{~min}$ at $26^{\circ} \mathrm{C}$. Nuclear-labeled RNA was extracted with TRI Reagent (Molecular Research Center, Inc). RNA was pelleted and resuspended in $200-\mu \mathrm{l}$ hybridization buffer (7\% SDS, $10 \%$ polyethylene glycol $(8,000), 1.5 \times$ sodium chloride sodium phosphate EDTA). Aliquots of RNA from treated and untreated samples were counted in a scintillation counter, and an equal number of counts from each condition $\left(1-2 \times 10^{6} \mathrm{cpm}\right.$ ) was hybridized to cDNAs (5 $\mu \mathrm{g}$ ) for PTH, calcitonin, actin, rat glyceraldehyde-3 phosphate dehydrogenase antisense vitamin D receptor (VDR) RNA (synthesized from pGEM zf (+) vector using T7 polymerase), and pBR322 which were immobilized to Hybond filters (Amersham International) using a slot blot apparatus.

Hybridization was performed at $65^{\circ} \mathrm{C}$ for $72 \mathrm{~h}$. The filters were washed three times at room temperature in $2 \times$ SSC, $0.2 \%$ SDS for 5 min, then washed once at $55^{\circ} \mathrm{C}$ for $15 \mathrm{~min}$. The blots were exposed to CURIX-RP2 film (AGFA Corp., Orangeburg, NY) at $-70^{\circ} \mathrm{C}$ with intensifying screens for $\mathbf{1 4} \mathrm{d}$. In addition, the filters were exposed for $24 \mathrm{~h}$ to a Bio Imaging Plate and quantified by a Bio-imaging analyzer BAS2000 (Fuji Photo Film Co., Tokyo Japan).

In situ hybridization. Formaldehyde fixed paraffin embedded thyroparathyroid gland sections $(8 \mu \mathrm{m})$ were collected on gelatine-coated glass slides, dewaxed, and dehydrated in graded ethanol solutions. Sections were hybridized using DNA color kits for nonradioactive in situ hybridization (Amersham International) using a random primed fluorescein labeled DNA probe for PTH. For detection the slides were incubated with antifluorescein alkaline phosphatase conjugate followed by the addition of NBT (nitro blue tetrazolium)/BCIP (5-bromo-4chloro-3 indolyl phosphate) substrate. The resulting colored precipitate was visualized by light microscopy. In addition in situ hybridization was performed using an RNA color kit (Amersham International) with antisense and sense RNA probes for PTH.

Serum measurements. Serum calcium and phosphate were measured in a autoanalyzer (Hoffmann-LaRoche \& Co., Nutley, NJ). Serum $1,25(\mathrm{OH})_{2} \mathrm{D}_{3}$ levels were measured by a radioreceptor assay (Incstar Corp., Stillwater, OK). Serum iPTH levels were measured with a rat immunoradiomimetric assay (Nichols, San Clemente, CA). Statistical analysis was performed on the Macintosh program Statview 512+ (Abacus Concepts, Inc., Berkeley, CA), using Students' unpaired two-tailed $t$ test. The results are presented as the mean \pm SEM.

\section{Results}

Animal studies. After $3 \mathrm{wk}$ of the diets the serum phosphate was lower in the rats fed $0.02 \%$ phosphate than those fed a

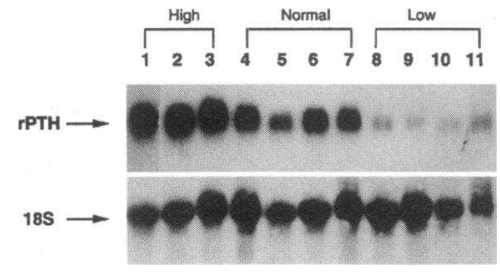

Figure 1. Effect of dietary phosphate on rat PTH mRNA $(r P T H)$. Weanling rats were fed the different diets for 3 wk before surgery. Gel blot analysis of total RNA from thyropara-

thyroid tissue from rats hybridized with ${ }^{32} \mathrm{P}$ random primed cDNA for rat PTH and 18S RNA. Lanes 1-3, high phosphate, high calcium ( $1.2 \%$ phosphate, $1.2 \%$ calcium); lanes $4-7$, controls $(0.3 \%$ phosphate, $0.6 \%$ calcium); lanes $8-11$, low phosphate $(0.02 \%$ phosphate, $0.6 \%$ calcium). Each lane represents total RNA from thyroparathyroid tissue of a single rat.

normal $(0.3 \%)$ or a high phosphate $(1.2 \%)$ (Table I), although there was also an increase in their serum calciums, and a large increase in their serum $1,25(\mathrm{OH})_{2} \mathrm{D}_{3}$ levels (Table I). A high serum phosphate leads to hypocalcemia, therefore the diet with a high phosphate $(1.2 \%)$ included a high calcium $(1.2 \%)$ to prevent the hypocalcemia. Rats fed this diet had normal serum phosphate and calcium levels (Table I). Levels of PTH mRNA were much lower in the rats with the low serum phosphate, as compared to the normal serum phosphate rats (Fig. 1). The rats fed a high phosphate, high calcium diet had an increase in their PTH mRNA (Fig. 1). The filters were hybridized for 18S RNA to confirm equal loading of the gels. Similar results were found in three repeat experiments in which rats were fed the different diets for $3 \mathrm{wk}$ and they are shown quantitatively in Fig. 2. The PTH mRNA levels in rats on a low phosphate diet were $25 \pm 8 \%$ of the control rats $(P<0.01)$. A high phosphate diet led to an increase in PTH mRNA levels $(P<0.01)$, despite the normal serum phosphate levels in this group. The effect of low phosphate to decrease PTH mRNA levels was also present after 4, 10 , and $14 \mathrm{~d}$ of the diet (not shown). Serum iPTH levels at 14 $\mathrm{d}$ in control rats were $22.1 \pm 3.7 \mathrm{pg} / \mathrm{ml}$, and in rats after $14 \mathrm{~d}$ of a low phosphate diet they were $4.7 \pm 0.8 \mathrm{pg} / \mathrm{ml}(P<0.05)$, which were similar to those of parathyroidectomized rats at 7 $\mathrm{d}(3.4 \pm 1.0 \mathrm{pg} / \mathrm{ml})$ and $14 \mathrm{~d}(3.3 \pm 0.2 \mathrm{pg} / \mathrm{ml})$. Serum calcium and phosphate levels in rats fed a low phosphate diet at $14 \mathrm{~d}$ were the same as at $21 \mathrm{~d}$ (Table I).

To visualize the effect of a low phosphate diet on PTH mRNA in situ hybridization studies were performed. Thyroparathyroid tissue from a rat fed a normal diet and from a rat fed a low phosphate diet was fixed to the same glass slide to allow

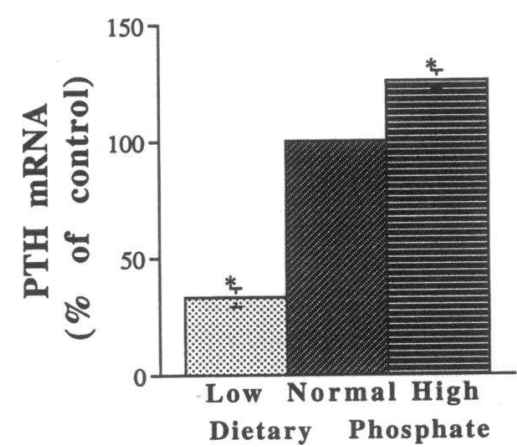

Figure 2. Effect of dietary phosphate on PTH mRNA levels of rat thyroparathyroid glands. Weanling rats were fed the different diets for 3 wk before surgery. The mean \pm SE for three different experiments is shown, with three to four rats in each dietary group in the different experiments. The PTH mRNA levels are shown for rats on low, normal, and high phosphate diets (as in Fig. 1). ${ }^{*} P$ $<0.01$ in comparison to normal diet. 

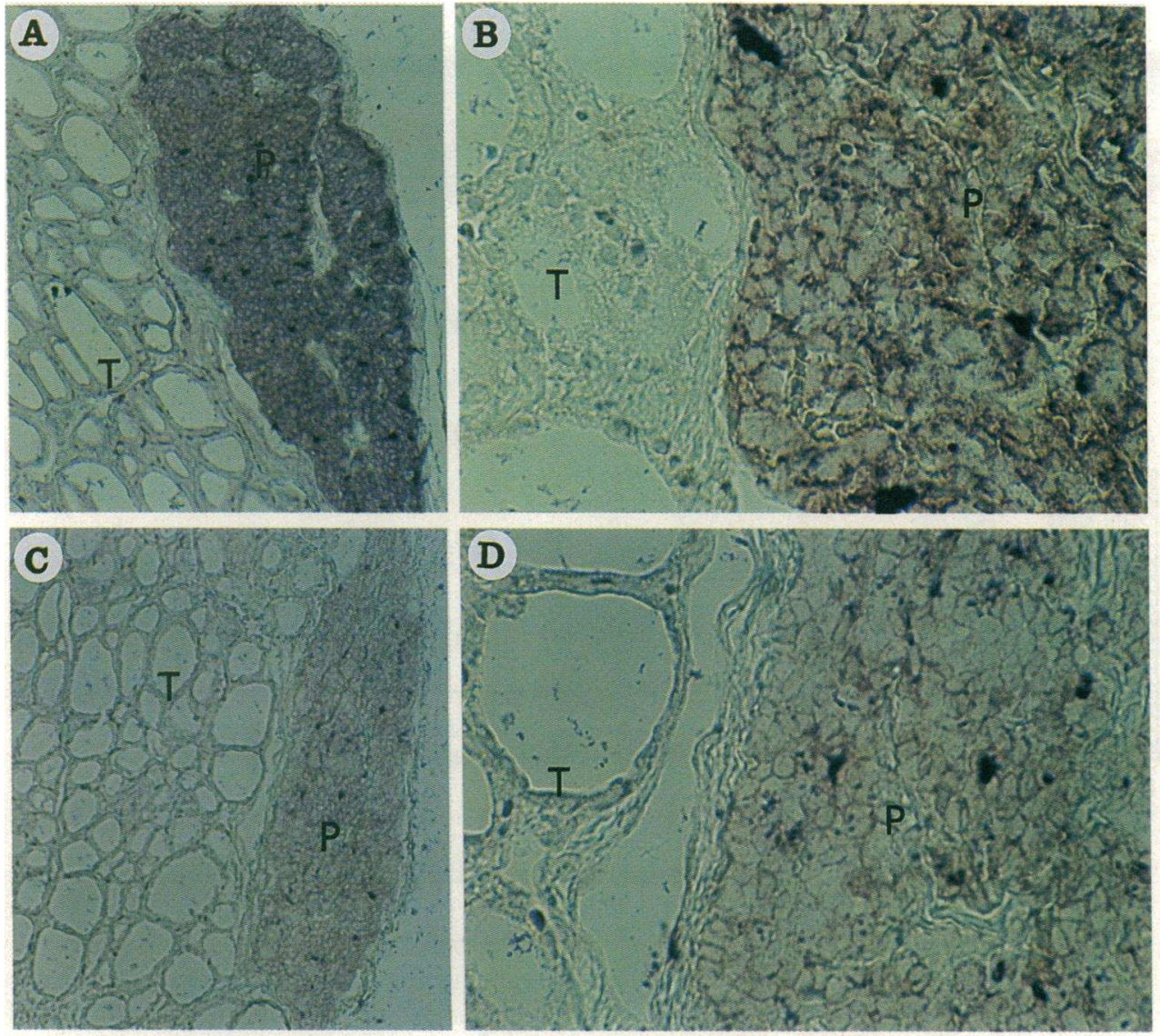

Figure 3. In situ hybridization of parathyroid-thyroid sections with PTH probe. $(A)$ Parathyroid-thyroid tissue from a control rat with the parathyroid $(P)$ staining darkly for the PTH mRNA. There is no staining of the thyroid $(T)(\times 125)$. (B) A higher power view of one $A$ showing the parathyroid cells $(P)$ and thyroid follicles $(T)(\times 500)$. (C) Parathyroid-thyroid tissue from a rat which had been fed a low phosphate diet for 2 wk showing the much lighter staining for PTH mRNA in the parathyroid $(P)$ and none present in the thyroid $(T)$ $(\times 125)$. (D) A higher power view of $C(\times 500)$. comparison of the in situ signal. PTH mRNA was localized solely to the parathyroid with none present in the surrounding thyroid (Fig. 3). A high power view showed that PTH mRNA was localized to the periphery of the parathyroid cells and was present unformly in all parathyroid cells. In a rat which had been fed a low phosphate diet for 2 wk there was much less PTH mRNA in the parathyroid. The PTH mRNA was still localized to the periphery of the parathyroid cells and the reduced mRNA affected all the cells. Identical results were found in four other sets of glands (not shown). In situ hybridization using an RNA antisense probe for PTH showed the same result and there was no labeling with the control sense RNA probe (not shown).

To separate the effect of low phosphate from that of a high serum calcium, groups of weanling rats were fed a diet which was vitamin D-deficient, with a low content of both phosphate $(0.02 \%)$ and calcium $(0.02 \%)$ for 10 and $14 \mathrm{~d}$ (Fig. 4$)$. The serum phosphates were markedly reduced at 10 and $14 \mathrm{~d}$ and the serum calciums did not increase at both 10 and $14 \mathrm{~d}$ (Fig. 4). There was an increase in serum $1,25(\mathrm{OH})_{2} \mathrm{D}$ levels (Fig. 4). PTH mRNA and serum iPTH levels were decreased to the same degree as for rats fed the low phosphate diet with a normal calcium content.

Vitamin D-deficient rats. Second generation vitamin Ddeficient rats fed a low phosphate diet for 10 and $21 \mathrm{~d}$ had increased levels of serum calcium, decreased serum phosphates, and the same levels of serum $1,25(\mathrm{OH})_{2} \mathrm{D}_{3}$ (Table II). PTH mRNA levels were markedly decreased in the vitamin D-deficient rats fed the low phosphate diets for both $10 \mathrm{~d}$ (Fig. 5) and 3 wk (not shown) despite the normal serum $1,25(\mathrm{OH})_{2} \mathrm{D}_{3}$ levels (Table II).

In a further experiment second generation vitamin D-deficient rats were fed diets with both a low calcium $(0.02 \%)$ and phosphate $(0.02 \%)$ or a normal calcium $(0.6 \%)$ and phosphate $(0.3 \%)$. At $1 \mathrm{~d}$ there was a low serum phosphate with normal serum calcium and $1,25(\mathrm{OH})_{2} \mathrm{D}$ levels in the rats fed the low calcium, low phosphate diet as compared to their controls fed a normal calcium, normal phosphate diet (Fig. 6). PTH mRNA levels were markedly reduced (Fig. 6). There was no change in a control gene $18 \mathrm{~S}$ RNA $(10.9 \pm 2.9: 11.8 \pm 0.8$ OD units, $P$ $=$ NS). Therefore hypophosphatemia decreased PTH mRNA with no change in serum calcium or $1,25(\mathrm{OH})_{2} \mathrm{D}$.

Nuclear transcript run-ons. Nuclear transcript run-on assays were performed on nuclei from the thyroparathyroid tissue from groups of weanling rats fed normal and low phosphate diets for 2 wk. Hybridization of the labeled RNA synthesized in vitro to cDNAs immobilized on filters showed that there was no difference in the transcription of PTH from rats on a low phosphate diet as compared to a normal diet (Fig. 7). There was also no difference in the transcription of two control genes actin and rat glyceraldehyde- 3 phosphate dehydrogenase, as well as the $1,25(\mathrm{OH})_{2} \mathrm{D}_{3}$ receptor (VDR) and calcitonin genes. These results were confirmed quantitatively by an image analyzer. A repeat experiment demonstrated identical results.

\section{Discussion}

The present study demonstrates that dietary phosphate regulates PTH gene expression in vivo in the rat. The effect of a low 


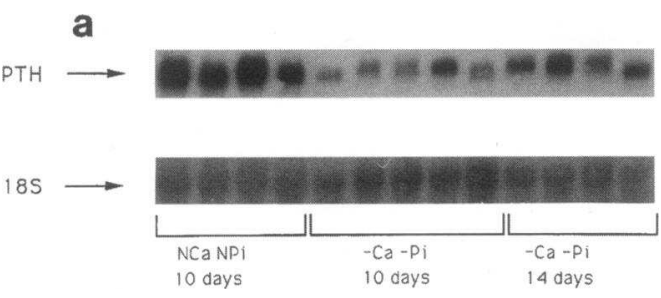

b
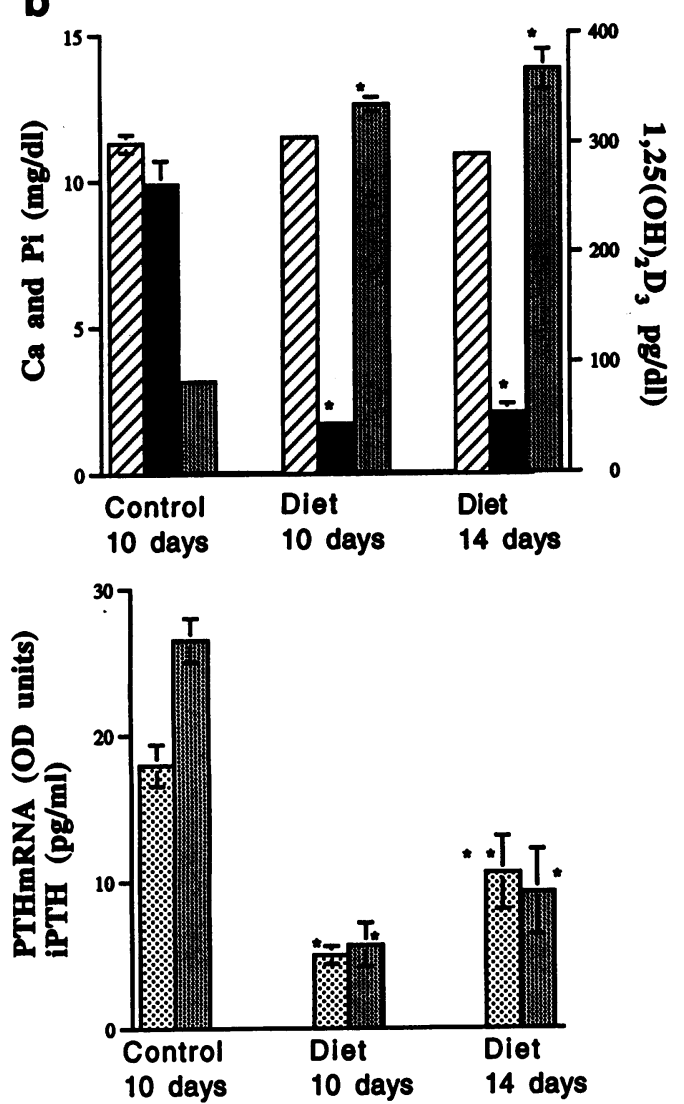

Figure 4. Effect of a diet with both low phosphate and calcium on serum calcium, phosphate, $1,25(\mathrm{OH})_{2} \mathrm{D}$, and $\mathrm{iPTH}$ and PTH mRNA levels at days 10 and 14. (a) Gel blot analysis of total RNA from thyroparathyroid tissue from rats hybridized with ${ }^{32} \mathrm{P}$ random primed cDNA for rat PTH and 18S RNA. Lanes $1-4$, control at $10 \mathrm{~d}$; lanes 5-9, low calcium $(0.02 \%)$ low phosphate $(0.02 \%)$ at $10 \mathrm{~d}$; lanes $10-$ 13, low calcium low phosphate at $14 \mathrm{~d}$. (b) Bar graph of levels of serum calcium $(\nabla)$, phosphate $(\mathbb{E})$, and $1,25(\mathrm{OH})_{2} \mathrm{D}(\mathbb{0})$ which are shown above, and serum iPTH (웅) and tissue PTH mRNA (앙) below. The data are represented as day 10 for control diet, and 10 and 14 of the experimental diet. Each point represents the mean $\pm S E$ of four rats. Where no SE is shown it is because the SE was smaller than the line. $* P<0.001 ; * * P<0.05$.

phosphate diet was dramatic with a marked decrease in PTH mRNA levels and a decrease in serum iPTH levels to levels similar to those of rats after parathyroidectomy. Rats on the low dietary phosphate not only had low serum phosphate levels, but also had increased serum calcium and $1,25(\mathrm{OH})_{2} \mathrm{D}_{3}$ levels, in addition to their decreased PTH mRNA levels. To separate the effect of hypophosphatemia from that of hypercalcemia after a low phosphate diet, weanling rats were fed a diet deficient in vitamin $\mathrm{D}$ and with a low phosphate and calcium content. These rats developed hypophosphatemia with no increase in serum
Table II. The Effects of 10 and $21 d$ of Diets Given to Second Generation Vitamin D-Deficient Weanling Rats

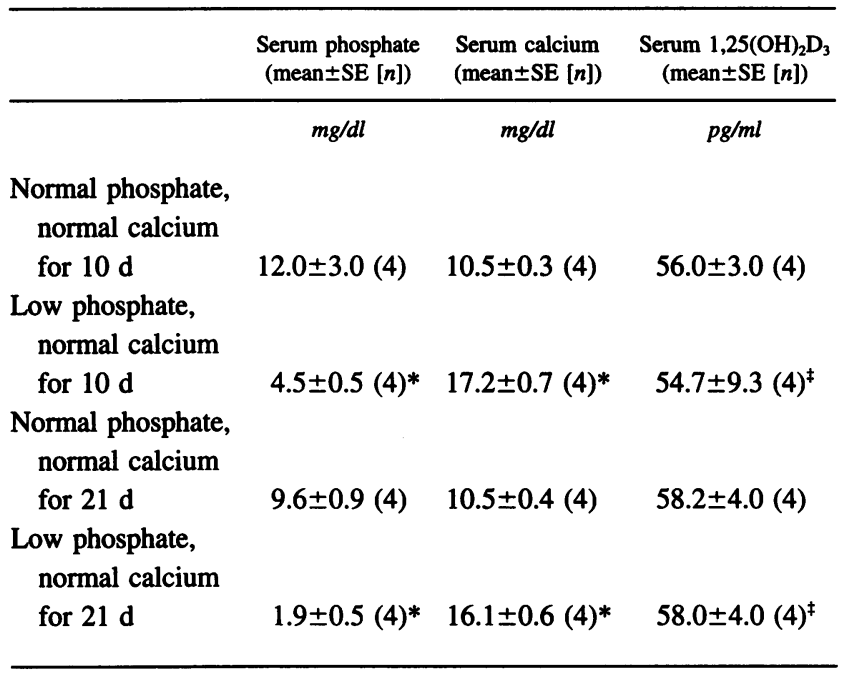

$n$, number of rats. ${ }^{*} P<0.01$, or ${ }^{\ddagger}$ NS compared with normal phosphate, normal calcium for the same time period.

calcium and their serum iPTH and PTH mRNA levels were reduced as before (Fig. 4). However serum $1,25(\mathrm{OH})_{2} \mathrm{D}$ levels in these rats were increased.

$1,25(\mathrm{OH})_{2} \mathrm{D}_{3}$ is an important factor in decreasing PTH gene transcription both in vivo in rats and in vitro in parathyroid cells. It was, therefore, possible that hypophosphatemia increased $1,25(\mathrm{OH})_{2} \mathrm{D}_{3}$ levels which then decreased PTH mRNA levels. To determine if the effect of phosphate was mediated by $1,25(\mathrm{OH})_{2} \mathrm{D}_{3}$ we performed studies on second generation vitamin $\mathrm{D}$-deficient rats. These rats fed a low phosphate diet from weaning had low serum phosphates and high serum calciums and no differences in their serum $1,25(\mathrm{OH})_{2} \mathrm{D}_{3}$ levels as compared to the rats fed a normal phosphate in their diets (Table II) and their PTH mRNA levels were still markedly reduced (Fig. 5). This indicates that the effect of phosphate in decreasing PTH gene expression, was not mediated solely by $1,25(\mathrm{OH})_{2} \mathrm{D}_{3}$, and the effect of $1,25(\mathrm{OH})_{2} \mathrm{D}_{3}$ would therefore be an additional effect. To determine whether hypophosphatemia alone with no hypercalcemia and no increase in serum $1,25(\mathrm{OH})_{2} \mathrm{D}$ regulated the parathyroid gland, weanling rats were fed a diet deficient in vitamin $\mathrm{D}$ and with a low phosphate and calcium content. After $1 \mathrm{~d}$ of this diet there was a decrease in serum phosphate and thyroparathyroid PTH mRNA levels with no change in serum calcium or $1,25(\mathrm{OH})_{2} \mathrm{D}$ levels (Fig.

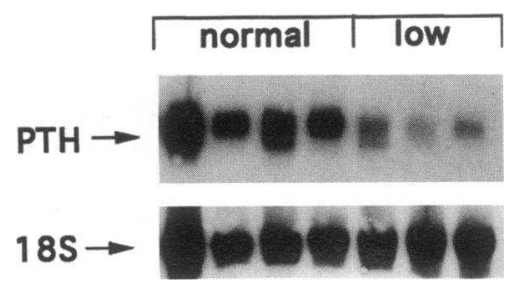

Figure 5. Effect of dietary phosphate on PTH mRNA levels in second generation vitamin $\mathrm{D}$ deficient rats fed either normal or low phosphate diets for $10 \mathrm{~d}$. 18S RNA is shown as a control for the amount of RNA on the filter. Each lane represents total RNA from thyroparathyroid tissue of a single rat. 


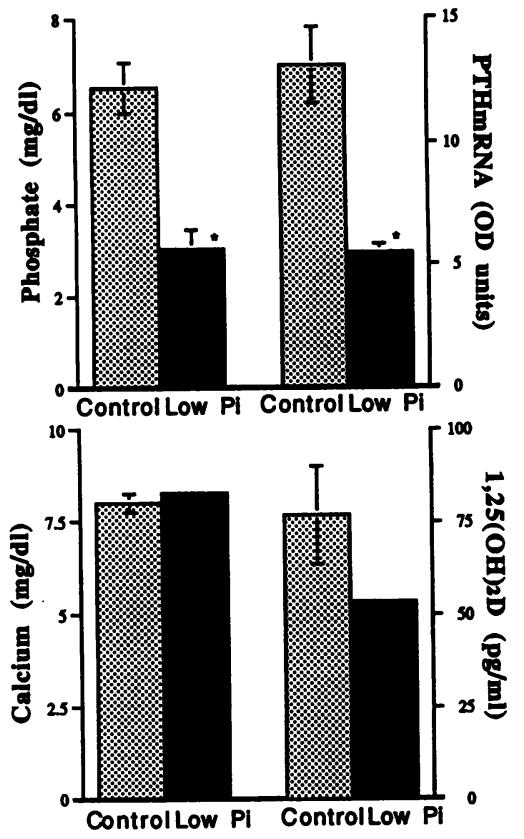

Figure 6. Effect of dietary phosphate on PTH mRNA levels in second generation vitamin Ddeficient rats fed a vitamin D-deficient diet with both a low phosphate and calcium content for $1 \mathrm{~d}$. Levels of serum phosphate and PTH mRNA (top), and serum calcium and $1,25(\mathrm{OH})_{2} \mathrm{D}_{3}$ (bottom) for rats fed a vitamin Ddeficient, normal phosphate, normal calcium diet (control group), or a vitamin D-deficient, low phosphate, low calcium diet for $1 \mathrm{~d}$. The results are the mean \pm SE for five rats in each group; ${ }^{*} P \leq 0.01$. Data for $1,25(\mathrm{OH})_{2} \mathrm{D}_{3}$ represent pooled serum

from two or three rats with three samples for control rats and two samples for low phosphate rats.

6). This indicates that hypophosphatemia itself decreases PTH mRNA levels without a contribution of calcium or vitamin D. We provided further evidence that the effect of hypophosphatemia was not mediated by vitamin $\mathrm{D}$ by showing that the effect was not transcriptional. The effect of $1,25(\mathrm{OH})_{2} \mathrm{D}_{3}$ on the PTH gene is transcriptional (2) and therefore, if the effect of phosphate was mediated by its effect on serum $1,25(\mathrm{OH})_{2} \mathrm{D}_{3}$ levels, then it would be a transcriptional effect. We had previously shown in vivo in rats injected with single doses of $1,25(\mathrm{OH})_{2} \mathrm{D}_{3}$ that PTH transcription rates decreased to $10 \%$ of controls (2). We performed nuclear transcript run-ons on thyroparathyroid tissue from rats fed a normal or phosphatedeficient diet which showed that the effect of low phosphate was not transcriptional (Fig. 7). This result further supports the conclusion that the effect of phosphate on PTH gene expression is not mediated by $1,25(\mathrm{OH})_{2} \mathrm{D}_{3}$.

We performed in situ hybridization to visualize the effect of a low phosphate diet on PTH mRNA levels (Fig. 3). In a control rat PTH mRNA was present in all the parathyroid cells and localized to the periphery of the cell. This localization of mRNAs within a cell is often related to their trafficking within the cell (13) and the particular position of the PTH mRNA might represent a stage in its passage onto translation and availability for secretion. After a low phosphate diet there was a uniform and marked reduction in PTH mRNA (Fig. 3).

Not only did a low phosphate decrease PTH mRNA levels in vivo, but a high phosphate diet led to an increase in PTH mRNA levels, despite the finding that the rats were not hyperphosphatemic. The effect of the high phosphate diet might possibly reflect a transient hyperphosphatemia which was not detected in the present study, or a change in intracellular phosphate which was not studied here. The present studies therefore show that phosphate regulates PTH gene expression. Phosphate has been shown to have an effect on serum PTH levels in a number of studies. Lopez-Hilker et al. have shown in dogs with experi-

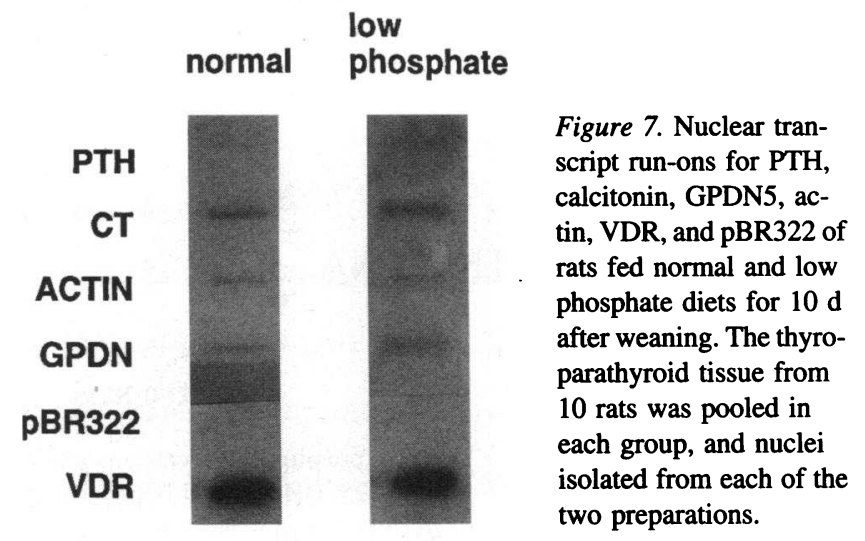

mental chronic renal failure that phosphate restriction corrected their secondary hyperparathyroidism independent of changes in serum calcium and $1,25(\mathrm{OH})_{2} \mathrm{D}_{3}$ levels (14). They did this by placing the uremic dogs on diets deficient in both calcium and phosphate, which led to lower levels of serum phosphate and calcium, with no increase in the low levels of serum $1,25(\mathrm{OH})_{2} \mathrm{D}_{3}$. Despite this there was a $70 \%$ decrease in PTH levels. Lopez-Hilker's study on the effect of a low phosphate diet on serum PTH levels suggested that phosphate had an effect on the parathyroid cell by a mechanism independent of its effect on serum $1,25(\mathrm{OH})_{2} \mathrm{D}_{3}$ and calcium levels (14). Sherwood et al. injected phosphate to cows and showed that phosphate caused no direct effect on PTH secretion, but stimulated the parathyroid glands by lowering the serum calcium (15). In those studies the effect of hypophosphatemia was not investigated, nor was the effect of a more prolonged phosphate infusion studied.

Phosphate retention has long been considered to be important to the pathogenesis of the secondary hyperparathyroidism of chronic renal failure, and the resultant disabling renal osteodystrophy. In the '70s Slatopolsky and Bricker showed in dogs with experimental chronic renal failure that dietary phosphate restriction prevented their secondary hyperparathyroidism (16). Clinical studies (17) have demonstrated that phosphate restriction in patients with chronic renal insufficiency is effective in preventing the increase in serum PTH levels (1721). The mechanism of this effect was not clear, although at least part of it was considered to be due to changes in serum $1,25(\mathrm{OH})_{2} \mathrm{D}_{3}$ concentrations. In vitro $(10,22)$ and in vivo $(17,23)$ phosphate directly regulated the production of $1,25(\mathrm{OH})_{2} \mathrm{D}_{3}$. A raised serum phosphate decreases serum $1,25(\mathrm{OH})_{2} \mathrm{D}_{3}$ levels and serum calcium by formation of calcium phosphate in the serum which is then deposited in bone and soft tissues. Therefore, phosphate undoubtedly plays a central role in the pathogenesis of secondary hyperparathyroidism, both by its effect on serum $1,25(\mathrm{OH})_{2} \mathrm{D}_{3}$, calcium levels, and independently.

The parathyroids hyperfunction in secondary hyperparathyroidism at a number of levels. Firstly, there is an increase in PTH secretion, which is due to the low calcium of chronic renal failure. It is also controversial whether there is an alteration in parathyroid cell sensitivity (set point) to levels of calcium which would normally decrease PTH secretion $(24,25)$. PTH synthesis is increased because of increased PTH gene expression per cell (8), and also in the long term, because of an increased number of parathyroid cells. Naveh-Many and Silver 


\section{Bequlation of PTH Gene Exoression}

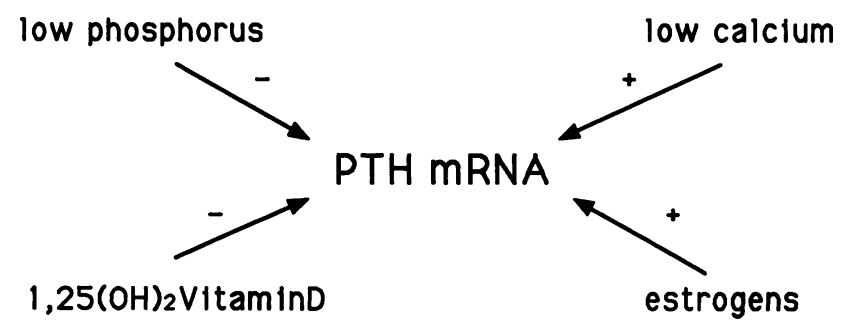

Figure 8. The regulation of PTH gene expression. Hypocalcemia and estrogens increase PTH mRNA levels. $1,25(\mathrm{OH})_{2} \mathrm{D}_{3}$ and hypophosphatemia decrease PTH mRNA levels. Not shown is the effect of a high phosphate to increase PTH mRNA levels.

showed that weanling rats maintained for 3 wk on diets deficient in vitamin D and calcium had a 10 -fold increase in PTH mRNA levels, which was mainly due to an increase in PTH gene expression per cell with a much smaller contribution of increased cell number (8). They, therefore, demonstrated that changes in PTH gene expression are an important factor in the pathogenesis of secondary hyperparathyroidism. The present study indicates that changes in serum phosphate also regulate PTH gene expression either by a direct or indirect action on the parathyroid cell, and a raised serum phosphate would increase PTH mRNA levels and contribute to the pathogenesis of secondary hyperparathyroidism.

It is not known how phosphate would directly affect the parathyroid cell. Phosphate equilibrates across cell membranes by active and inactive transport mechanisms, and the changes in extracellular phosphate might very well be reflected by changes in intracellular phosphate, as well as by changes in membrane phospholipid composition. For example, one phospholipid, inositol triphosphate is an important second messenger in all cells $(26)$, including the parathyroid $(27,28)$. Bourdeau et al. have shown that both calcium and $1,25(\mathrm{OH})_{2} \mathrm{D}_{3}$ led to rapid ( $5 \mathrm{~s}$ ) increases in phosphatidinyl metabolites in porcine parathyroid cells (29). It would be intriguing to determine the interactions in the parathyroid cell of changes in calcium, phosphate, and $1,25(\mathrm{OH})_{2} \mathrm{D}_{3}$.

The effect of changes in serum calcium on PTH gene expression and secretion are better understood. We $(6,8)$ and Yamamoto et al. (7) have shown that a low serum calcium leads to marked increases in PTH mRNA levels. However, we have increased serum calcium by a number of methods for periods from $6 \mathrm{~h}$ to $3 \mathrm{wk}$ and showed that a high serum calcium had no effect on PTH mRNA levels in vivo, despite serum calciums as high as $25 \mathrm{mg} / \mathrm{dl}(6,30)$ although a modest effect of a calcium infusion for $48 \mathrm{~h}$ has been demonstrated (7). The mechanism of calcium sensing by the parathyroid cell is through a calcium receptor which is G-protein coupled and activates inositol triphosphate production (31). Studies on the action of phosphate on the parathyroid cell in vitro, for instance in primary cultures of bovine parathryoid cells, have not produced positive results which would allow studies on a signal transduction pathway. It is possible that the effect of phosphate is directly on the parathyroid cell or it is just as reasonable to hypothesize that it is an indirect effect by a mechanism not involving calcium or vitamin D. Changes in extracellular phosphate concentration do directly produce changes in cells. For instance, a low phos- phate medium leads to an increase in phosphate transport by renal and other cells in culture (32-34) which is not secondary to changes in ATP or ADP concentration $(35,36)$, and is associated with a decrease in intracellular calcium concentration (37). The physiology of phosphate effect on the parathyroid remains to be elucidated.

In any event it is now clear that the parathyroid cell, and particularly the expression of the parathyroid gene respond to a number of factors, such as $1,25(\mathrm{OH})_{2} \mathrm{D}_{3}$, calcium, estrogens, and now phosphate (Fig. 8). Changes in the concentrations of these factors lead to the altered synthesis and secretion of PTH, which is important to the pathogenesis of disabling diseases such as renal osteodystrophy and osteoporosis. The effective prevention and treatment of these diseases is dependent on advances in our understanding of their pathophysiology, such as how the expression of the PTH gene is regulated by phosphate.

\section{Acknowledgments}

The authors acknowledge Ms. Miriam Offner for excellent technical assistance, $\mathrm{S}$. Edelstein of the Weizmann Institue for performing the serum $1,25(\mathrm{OH})_{2} \mathrm{D}_{3}$ assays and to $\mathrm{C}$. R. Kleeman for helpful discussions.

This work was supported by the Thyssen Foundation.

\section{References}

1. Silver, J. 1992. Regulation of parathyroid hormone synthesis and secretion. In Disorders of Bone and Mineral Metabolism, F. L. Coe and M. J. Favus, editors Raven Press, Ltd., New York. 83-106.

2. Silver, J., T. Naveh-Many, H. Mayer, H. J. Schmelzer and M. M. Popovtzer. 1986. Regulation by vitamin D metabolites of parathyroid hormone gene transcription in vivo in the rat. J. Clin. Invest. 78:1296-1301.

3. Silver, J., J. Russell, and L. M. Sherwood. 1985. Regulation by vitamin D metabolites of messenger ribonucleic acid for preproparathyroid hormone in isolated bovine parathyroid cells. Proc. Natl. Acad. Sci. USA. 82:4270-4273.

4. Okazaki, T., T. Igarashi, and H. M. Kronenberg. 1988. 5 '-flanking region of the parathyroid hormone gene mediates negative regulation by $1,25(\mathrm{OH}) 2$ vitamin D3. J. Biol. Chem. 263:2203-2208.

5. Demay, M. B., M. S. Kiernan, H. F. DeLuca, and H. M. Kronenberg 1992. Sequences in the human parathyroid hormone gene that bind the 1,25 dihydroxyvitamin D3 receptor and mediate transcriptional repression in response to 1,25-dihydroxyvitamin D3. Proc. Natl. Acad. Sci. USA. 89:8097-8101.

6. Naveh-Many, T., M. M. Friedlaender, H. Mayer, and J. Silver. 1989. Calcium regulates parathyroid hormone messenger ribonucleic acid (mRNA), but not calcitonin mRNA in vivo in the rat. Dominant role of 1,25-dihydroxyvitamin D. Endocrinology. 125:275-280.

7. Yamamoto, M., T. Igarashi, M. Muramatsu, M. Fukagawa, T. Motokura, and E. Ogata. 1989. Hypocalcemia increases and hypercalcemia decreases the steady-state level of parathyroid hormone messenger RNA in the rat. J. Clin. Invest. 83:1053-1056.

8. Naveh-Many, T., and J. Silver. 1990. Regulation of parathyroid hormone gene expression by hypocalcemia, hypercalcemia, and vitamin D in the rat. $J$. Clin. Invest. 86:1313-1319.

9. Naveh-Many, T., G. Almogi, N. Livni, and J. Silver. 1992. Estrogen receptors and biologic response in rat parathyroid tissue and C-cells. J. Clin. Invest. 90:2434-2438.

10. Tanaka, Y., and H. F. DeLuca. 1973. The control of vitamin D by inorganic phosphorus. Arch. Biochem. Biophys. 154:566-570.

11. Raynolds, M. V., P. D. Awald, D. F. Gordon, A. Guierrez-Hartmann, D. C. Rule, W. M. Wood, and R. H. Eckel. 1990. Lipoprotein lipase gene expression in rat adipocytes is regulated by isoproterenol and insulin through different mechanisms. Mol. Endocrinol. 4:1416-1422.

12. Groudine, M., M. Peretz, and H. Weintraub. 1981. Transcriptional regulation of hemoglobin switching in chicken embryos. Mol. Cell. Biol. 1:281-288.

13. Lawrence, J. B., and R. H. Singer. 1986. Intracellular localization of messenger RNAs for cytoskeletal proteins. Cell. 45:407-415.

14. Lopez-Hilker, S., A. S. Dusso, N. S. Rapp, K. J. Martin, and E. Slatopolsky. 1990. Phosphorus restriction reverses hyperparathyroidism in uremia independen of changes in calcium and calcitriol. Am. J. Physiol. 259:F432-F437.

15. Sherwood, L. M., G. P. Ayer, C. F. Ramberg, D. S. Kronfeld, G. D. Aurbach, and J. T. Potts Jr. 1968. Regulation of parathyroid hormone secretion: 
proportional control by calcium, lack of effect of phosphate. Endocrinology. 83:1043-1051.

16. Slatopolsky, E., and N. S. Bricker. 1973. The role of phosphorus restriction in the prevention of secondary hyperparathyroidism in chronic renal disease. Kidney Int. 4:141-145.

17. Portale, A. A., B. E. Booth, B. P. Halloran, and R. C. J. Morris. 1984. Effect of dietary phosphorus on circulating concentrations of 1,25-dihydroxyvitamin D and immunoreactive parathyroid hormone in children with moderate renal insufficiency. J. Clin. Invest. 73:1580-1589.

18. Lucas, P. A., R. C. Brown, J. S. Woudhead, and G. A. Coles. 1986 1,25-dihydroxycholecalciferol and parathyroid hormone in advanced chronic rena failure: effects of simultaneous protein and phosphorus restriction. Clin. Nephrol. 25:7-10.

19. Lafage, M. H., C. Combe, A. Fournier, and M. Aparicio. 1992. Ketodiet, physiological calcium intake and native vitamin $\mathrm{D}$ improve renal osteodystrophy. Kidney Int. 42:1217-1225.

20. Combe, C., and M. Aparicio. 1994. Phosphorus and protein restriction and parathyroid function in chronic renal failure. Kidney Int. 46:1381-1386.

21. Aparicio, M., C. Combe, M. H. Lafage, V. De Precigout, L. Potaux, and J. L. Bouchet. 1994. In advanced renal failure, dietary phosphorus restriction reverses hyperparathyroidism independent of the levels of calcitriol. Nephron. 63:122-123.

22. Condamine, L., F. Vztovsnik, G. Friedlander, C. Menaa, and M. Garabedian. 1994. Local action of phosphate depletion and insulin-like growth factor 1 on in vitro production of 1,25-dihydroxyvitamin D by cultured mammalian kidney cells. J. Clin. Invest. 94:1673-1679.

23. Portale, A. A., B. P. Halloran, and J. Curtis Morris. 1989. Physiologic regulation of the serum concentration of 1,25-dihydroxyvitamin $D$ by phosphorus in normal men. J. Clin. Invest. 83:1494-1499.

24. Brown, E. M., R. E. Wilson, R. C. Eastman, J. Pallotta, and S. P. Marynick. 1982. Abnormal regulation of parathyroid hormone release by calcium in secondary hyperparathyroidism due to chronic renal failure. J. Clin. Endocrinol. \& Metab. 54:172-179.

25. Ramirez, J. A., W. G. Goodman, J. Gornbein, C. Menezes, L. Moulton, G. V. Segre, and I. B. Salusky. 1993. Direct in vivo comparison of calciumregulated parathyroid hormone secretion in normal volunteers and patients with secondary hyperparathyroidism. J. Clin. Endocrinol. \& Metab. 76:1489-1494.
26. Berridge, M. J., and R. F. Irvine. 1989. Inositol phosphates and cell signalling. Nature (Lond.). 341:197-206.

27. Brown, E. M., J. Redgrave, and J. Thatcher. 1984. Effect of the phorbo ester TPA on PTH secretion. Evidence for a role for protein kinase $\mathrm{C}$ in the control of PTH release. FEBS (Fed. Eur. Biochem. Soc.) Lett. 175:72-75.

28. Brown, E. M. 1991. Extracellular Ca2+ sensing, regulation of parathyroid cell function, and role of $\mathrm{Ca} 2+$ and other ions as extracellular (first) messengers. Physiol. Rev. 71:371-411.

29. Bourdeau, A., J.-C. Souberbielle, P. Bonnet, P. Herviaux, C. Sachs, and $M$. Lieberherr. 1992. Phospholipase- $A_{2}$ action and arachidonic acid in calciummediated parathyroid hormone secretion. Endocrinology. 130:1339-1344.

30. Naveh-Many, T., F. Raue, A. Grauer, and J. Silver. 1992. Regulation of calcitonin gene expression by hypocalcemia, hypercalcemia, and vitamin D in the rat. J. Bone. Miner. Res. 7:1233-1237.

31. Brown, E. M., G. Gamba, R. Riccardi, M. Lombardi, R. Butters, O. Kifor, A. Sun, M. A. Hediger, J. Lytton, and J. Hebert. 1993. Cloning and characterization of an extracellular $\mathrm{Ca}^{2+}$-sensing receptor from bovine parathyroid. Nature (Lond.). 366:575-580

32. Caverzasio, J., C. D. A. Brown, J. Biber, and J.-P. Bonjour. 1985. Adaptation of phosphate transport in phosphate-deprived LLC-PK 1 cells. Am. J. Physiol. 248:F122-F127.

33. Biber, J., J. Forgo, and $\mathrm{H}$. Murer. 1988. Modulation of $\mathrm{Na}^{+}-\mathrm{Pi}$ cotransport in opossum kidney cells by extracellular phosphate. Am. J. Physiol. 255:C155C161.

34. Escoubet, B., K. Djabali, and C. Amiel. 1989. Adaptation to $P_{i}$ deprivation of cell Na-dependent $P_{i}$ uptake: a widespread process. Am. J. Physiol. 256:C322C328.

35. Barac-Nieto, M., T. L. Dowd, R. K. Gupta, and A. Spitzer. 1991. Changes in NMR-visible kidney cell phosphate with age and diet: relationship to phosphate transport. Am. J. Physiol. 261:F153-F162.

36. Barac-Nieto, M., H. Corey, S. M. Liu, and A. Spitzer. 1993. Role of intracellular phosphate in the regulation of renal phosphate transport during development. Pediatr. Nephrol. 7:819-822.

37. Escoubet, B., M. C. Garestier, C. Le-Grimellec, and C. Amiel. 1993. Multiple modulation of $\mathrm{Na}$-dependent $\mathrm{Pi}$ uptake by cellular $\mathrm{Ca}$ in MDCK cells. Am. J. Physiol. 265:C19-C27. 